\title{
O JED
}

ISSN: 2166-2681 Print/ ISSN: 2690-0408 Online Volume 9, Issue 1 (2020), pp. 168-171

(C) Journal of Interdisciplinary Studies in Education http://ojed.org/jise

\section{The Remoteness of Remote Learning: A Policy Lesson from COVID19}

\author{
Rosalyn Eder \\ University of Fribourg, Swizerland
}

\begin{abstract}
The measures enforced by governments to contain the highly contagious COVID19 pathogen laid bare the deep inequalities that beset education systems around the world. The lockdowns and subsequent closures of educational institutions have amplified the gap between the rich and the poor, not just between the Global North and the Global South, but within countries as well. As of April 6th, UNESCO reported that 188 countries have temporarily closed its educational institutions, while several countries implemented localized closures, affecting 1,576,021,818 learners. Accordingly, education authorities have urged for classes at all levels to be moved online, a sudden but necessary emergency response to COVID19. However, for disadvantaged groups, the problem is how to meet the basic conditions that remote learning requires.
\end{abstract}

Despite the ubiquity of concepts such as Internet of Things (IoT), or Digital Transformations, the digital gap between the rich and the poor remains a hard fact. According to the International Telecommunication Union (2019), although 93 per cent of the world's population lives within reach of Internet service, only around 53 per cent actually uses the Internet. This is a paradox that could be explained in part by issues of affordability, especially in the Global South where internet access remains a luxury. A case in point is the protest by the General Tunisian Union of Students (UGET) against the proposal of the Ministry of Higher Education and Scientific Research to move to 
online formats. UGET maintains that it violates principles of equality and equal opportunities, because not all students have access to Internet, personal computer or electronic gadgets such as tablets and smartphones (Sawahel, 2020, para. 2). Parallel to this, institutions and educators have to equip themselves with the necessary tools and skills at a staggering speed to shift to remote learning. But, the majority of institutions and educators worldwide lack sophisticated technology and experience in designing online learning environments (Altbach \&amp; de Wit, 2020). Apart from online platforms, other forms of media, such as television or radio, could be used to reach those learners who don't have access to the internet. This is of course not news, but the use of mass media requires sufficient time for planning and production if they are to respond to the requirements of school curricula in basic education or to program content in higher education. But during a pandemic, time is of essence. Remote education also necessitates an environment and atmosphere that is conducive to effective teaching and learning. But when living spaces do not allow for some peace and quiet time and family situations (such as forced furlough, unemployment or caring responsibilities) is an additional stress factor, the quality of education experience could suffer and potentially cause frustration to both learners and educators. Educators and learners alike who are marginalized and disadvantaged are thus at risk to be pushed further back and be at the losing end of the COVID19 measures. Thus, digital divide is real and it has real consequences to learning outcomes and to job security of educators and administrative staff.

The United Nations has provided a list of best practices and possible responses to prevent further disruptions in education. An interesting approach that applies to educational policy is to practice the spirit of "doing no harm" in and through education. Borrowed from the health sector, this principle suggests that policymakers should ensure that plans and programs do not harm anyone, and that all learners stand to benefit from intervention measures. In the case of remote instruction, if only some group of learners will benefit while the rest does not, then it should not be rolled out. This is the stance taken by, for example the Philadelphia School District in the United States and the Department of Education in the Philippines. The principle of "doing no harm" should thus become an imperative, not only in times of crisis. It requires a change in the mindset of policymakers and politicians as to how they 
perceive and value education beyond metrics and economic approaches. On the other hand, it should not be used as an excuse to ignore the root causes of deep-seated education inequalities, such as unequal income opportunity, discrimination, or inadequate social policies to mitigate poverty. COVID19 pitchforked us into hitting that big red education reset button in terms of provision. Hopefully, policymakers and administrators will also take this opportunity to take a long, hard look at existing educational programs and policies and their serious implications to real and lived experiences of educators and learners during and beyond COVID19.

\section{References}

Altbach, P. G. \& de Wit, H. (2020, March). COVID-19: The internationalisation revolution that isn't. Retrieved from https://www.universityworldnews.com/post.php?story=202003121437283 70

Chang, G-C. \& Yano, S. (2020). How are countries addressing the Covid-19 challenges in education? A snapshot of policy measures. Retrieved from https://gemreportunesco.wordpress.com/2020/03/24/how-are-countriesaddressing-the-covid-19-challenges-in-education-a-snapshot-of-policymeasures/

GEM Report (2020, April). "Doing no harm" in and through education. Retrieved from https://gemreportunesco.wordpress.com/2020/04/06/doing-no-harmin-and-through-education/\#more-12830

International Telecommunication Union (2019). Measuring digital development Facts and figures 2019. Geneva, Switzerland: International Telecommunication Union.

Republic of the Philippines Department of Education (2020). Guidelines for the Remainder of School Year 2019-2020 in light of COVID-19 Measures (DepEd Memorandum No. 042, s. 2020). Retrieved from https://www.deped.gov.ph/covid-19/covid19-memoranda/

Sawahel, W. (2020, March). Union opposes online classes as 'violation of equality'. Retrieved from

https://www.universityworldnews.com/post.php?story=202003250831389 92

United Nations Educational, Scientific and Cultural Organization (2020). Distance learning solutions. Retrieved from https://en.unesco.org/covid19/educationresponse/solutions

Rosalyn Eder is a final year $\mathrm{PhD}$ candidate at the Department of Education, University of Fribourg in Switzerland, and a part-time lecturer and international academic coordinator in the tourism program at Salzburg University of Applied Sciences in Austria. She holds a master's degree in Educational Science from the University of Salzburg, Austria. Rosalyn has 
participated in several European projects and has acquired funding from the Swiss National Science Foundation in 2015 for an international exploratory workshop that explored post coloniality and the future of international education. She is an active member of the EAIE Expert Community on Access and Diversity, and on the advisory board of the Journal of Interdisciplinary Studies in Education. Rosalyn's research and teaching interests focus on globalization and education: internationalization, higher education, labour migration, educational policy, diversity and inclusion. Born and raised in Manila, Philippines, Rosalyn is a first-generation academic and second-generation migrant worker.

Manuscript submitted: April 25, 2020

Manuscript revised May 9, 2020

Accepted for publication: May 20, 2020 